УДК 378.115:37.04

DOI: https://doi.org/10.35387/od.1(19).2021.123-129

Топольник Яна Володимирівна

- доктор педагогічних наук, доцент, профресор кафредри педагогіки вищої школи ДВНЗ «Донбаський державний педагогічний університет»
Topolnyk Yana - Doctor of Pedagogical Sciences, Associate Professor, Professor of the Higher School Pedagogy Department of the SHEE "Donbas State Pedagogical University»

ORCID iD: https://orcid.org/ 0000-0001-7885-9454

E-mail: yannetkatop@gmail.com

\title{
ОСОБЛИВОСТІ ВИВЧЕННЯ НАВЧАЛЬНОЇ ДИСЦИПЛІНИ «ІСТОРІЯ РОЗВИТКУ ТЕОРІЇ ТА ПРАКТИКИ ОСВІТИ ДОРОСЛИХ І АНДРАГОГІКИ» В ПРОЦЕСІ ПІДГОТОВКИ МАЙБУТНІХ ВИКЛАДАЧІВ ЗАКЛАДІВ ВИЩОЇ ОСВІТИ
}

Анотація. В оглядовій статті окреслено особливості вивчення навчальної дисципліни «Історія розвитку теорії та практики освіти дорослих і андрагогіки» в прочесі підготовки майбутніх викладачів закладів вищої освіти. Зазначено, що можливість використання позитивних здобутків минулого допомагає простежити процес виникнення і розвитку різних моделей освіти дорослих, спрогнозувати їх фрункціонування та подальший поступ. Освіта дорослих тісно пов'язана з андрагогікою, яка обірунтовує напрями та організаційно-методичні засади андрагогічної моделі навчання дорослої людини. Розглянуто підходи до визначення поняття "андрагогіка». Визначено мету, об'єкт, предмет та завдання вивчення навчальної дисципліни. Передумовами вивчення $є$ набуті раніше компетентності та результати навчання $з$ визначених освітніх компонент. Наведено програмні (загальні та фрахові) компетентності, що будуть сформовані у здобувачів після успішного завершення вивчення курсу, та очікувані результати навчання. Зазначено тематику програми навчальної дисципліни. Серед методів навчання здобувачів виокремлено: поєднання традиційних та інтерактивних методів навчання $з$ використанням інноваційних технологій, наочні методи, практичні методи, відеометод. Звертається увага на те, що після успішного вивчення навчальної дисципліни здобувач вищої освіти зможе критично осмислювати теорії, основні концепції педагогічних технологій навчання дорослих, обирати технології навчання залежно від стратегічних цілей $i$ завдань, забезпечувати навчально-методичний супровід дорослих; розширювати фрахові компетенції та особистісний потенціал педагога-андрагога. Зроблено висновки про те, що вивчення навчальної дисципліни «Історія розвитку теорії та практики освіти дорослих і андрагогіки» сприяє опануванню майбутніми викладачами закладів вищої освіти особливостями провадження практичної роботи педагога-андрагога та 
розв'язання комплексних проблем у галузі профресійної діяльності. Окреслено перспективи подальших досліджень означеної проблеми.

Ключові слова: андрагогіка; освіта дорослих; викладач закладу вищої освіти; навчальна дисципліна; загальні компетентності; фахові компетентності.

Topolnyk Yana

\section{PECULIARITIES OF STUDYING THE ACADEMIC DISCIPLINE «HISTORY OF DEVELOPMENT OF THEORY AND PRACTICE OF ADULT EDUCATION AND ANDRAGOGY»IN THE PROCESS OF TRAINING FUTURE TEACHERS OF HIGHER EDUCATION INSTITUTIONS}

Abstract. The review article outlines the peculiarities of studying the academic discipline "History of the Theory and Practice of Adult Education and Andragogy" in the process of training future teachers of higher education. It is noted that the possibility of using the positive achievements of the past helps to trace the process of emergence and development of different models of adult education, to predict their functioning and further progress. Adult education is closely related to andragogy, which substantiates the directions and organizational and methodological principles of the andragogical model of adult learning. Approaches to the definition of "andragogy" are considered. The purpose, object, subject and tasks of studying the discipline are defined. Prerequisites for the study are previously acquired competencies in certain educational components. The program (general and professional) competencies that will be formed in the applicants after the successful completion of the course, and the expected learning outcomes are given. The topics of the curriculum are indicated. Among the methods of teaching applicants are: a combination of traditional and interactive teaching methods using innovative technologies, visual methods, practical methods, video methods. Attention is drawn to the fact that after successful study of the discipline the graduate will be able to critically comprehend theories, basic concepts of pedagogical technologies of adult learning, choose learning technologies depending on strategic goals and objectives, provide educational and methodological support for adults; to expand the professional competencies and personal potential of the teacher-andragogue. It is concluded that the study of the academic discipline "History of the theory and practice of adult education and andragogy" contributes to the mastery of future teachers of higher education features of the practical work of a teacher-andragogue and solving complex problems in the field of professional activity. Prospects for further research on this problem are outlined.

Key words: andragogy; adult education; teacher of higher education; academic discipline; general competencies; professional competencies.

Постановка проблеми, їі актуальність. Усвідомлення того, що сучасний стан освіти дорослих в Україні $€$ підсумком усієї попередньої 
історії розвитку освіти дорослого населення, дає змогу простежити еволюцію освіти дорослих в Україні та визначити прогностичні напрями ії розвитку. Історико-педагогічний аналіз вітчизняного досвіду розвитку освіти дорослих вказує на можливість використання позитивних здобутків минулого, допомагає простежити процес виникнення й розвитку різних моделей освіти дорослих, спрогнозувати їх функціонування та подальший поступ.

Соціально-економічні перетворення в Україні на початку XXI cт. зумовили значні зміни в освіті дорослих; ії̈ зміст наповнився новим цензом, з'явилися нові типи закладів вищої освіти різних форм акредитації (як державної, так і приватної форм власності). Освітньо-педагогічні зміни в національному масштабі відбулися в контексті загальних трансформацій, зумовлених розповсюдженням нових освітніх технологій, спрямованих на використання їх в особистісному розвитку дорослої людини; відбувається зміна формули «освіта на все життя» формулами "освіта через усе життя», «навчання тривалістю в життя», які наголошують на значущості неперервної освіти для розвитку особистості дорослої людини. Освіта дорослих тісно пов'язана з новою для України галуззю наукового знання андрагогікою, субдисципліною педагогіки, яка обґрунтовує напрями та організаційно-методичні засади андрагогічної моделі навчання дорослої людини. Така модель будується на андрагогічних принципах, що становлять фрундамент теорії навчання дорослих.

Аналіз останніх досліджень і публікацій. Проблему історії розвитку теорії та практики освіти дорослих в Україні досліджували Л. Вовк, Н. Коляда, О. Мартіросян, Н. Побірченко, Л. Сігаєва, Л. Тимчук, Л. Шинкаренко та ін.; вибрані аспекти проблеми відображені в наукових працях О. Аніщенко, О. Барабаш, Л. Березівської, З. Гіптерс, С. Дмитренко, Т. Завгородньої, О. Ковальчук, Л. Лук'янової, Г. Лях, З. Нагачевської, І. Руснака, О. Сухомлинської, Н. Чепурної, С. Черкасової та ін.

Отже, на сучасному етапі розвитку освіти накопичено ґрунтовні наукові наробки щодо вивчення проблеми історії розвитку теорії та практики освіти дорослих і андрагогіки, що, в свою чергу, потребує впровадження набутого досвіду в систему підготовки майбутніх викладачів закладів вищої освіти.

Мета статті - обґрунтувати особливості вивчення навчальної дисципліни «Історія розвитку теорії та практики освіти дорослих i андрагогіки» в процесі підготовки майбутніх викладачів закладів вищої освіти.

Виклад основного матеріалу. Історичний аналіз доводить, що предмет вивчення андрагогіки (від грец. aner, andros - дорослий чоловік, зрілий чоловік+ ago - веду) сфокусований у декількох контекстах: поперше, наука про навчання дорослих, обґрунтовує діяльність дорослого учня в процесі навчання; по-друге, розділ теорії навчання, що розкриває специфічні закономірності засвоєння знань і вмінь дорослим суб'єктом навчальної діяльності, а також особливості керівництва цією діяльністю 3 боку професійного педагога. Окрім поняття андрагогіка у спеціальній 
літературі використовуються поняття «педагогіка дорослих», «теорія освіти дорослих» тощо.

У науковому педагогічному співтоваристві дотепер немає єдності у визначенні поняття. Вирізняємо декілька підходів до визначення «андрагогіка» (Беспарточна, 2014).

Перший підхід базується на спростуванні всіх підстав вважати андрагогіку самостійною наукою. Захисники цієї позиції вважають, що навчання і освіта дорослих - галузь дослідження, що належить наукам, сформованим раніше (соціології, психології, антропології, економіки тощо).

Другий підхід (американських дослідників) вбачає в андрагогіці прагматичне і практичне значення, рецепти поводження дорослого учня і викладача під час навчання.

Третій підхід трактує андрагогіку як досить незалежну наукову дисципліну. Ця концепція одержала широку підтримку в Центральній і Східній Європі.

Прихильники четвертого підходу розглядають андрагогіку не просто окремо від педагогіки, а, як і педагогіку, складовою інтегральної науки про навчання і освіту людини впродовж усього життя.

Мета навчальної дисципліни «/сторія розвитку теорії та практики освіти дорослих $i$ андрагогіки»: забезпечення загальної теоретичної і практичної підготовки здобувачів другого (магістерського) рівня вищої освіти з питань історії розвитку теорії та практики освіти дорослих у контексті безперервного становлення особистості, яка слугуватиме основою для практичної роботи педагога-андрагога, що пов'язана з викладацькою діяльністю, розв'язанням комплексних проблем у галузі професійної діяльності. Об'єкт вивчення - історія становлення та розвитку системи освіти дорослих, предмет вивчення - процес розвитку теорії та практики освіти дорослих і андрагогіки.

Завдання вивчення навчальної дисципліни:

- опанування концептуальними та методологічними знаннями в галузі навчання дорослих у системі безперервної освіти, психологічного й технологічного забезпечення освітнього процесу;

- озброєння майбутніх педагогів-андрагогів технологіями педагогічної практики освіти дорослих різних країн у різні часи, спрямування на виявлення та оцінювання тенденцій їх розвитку з метою розв'язання значущих проблем у сфері професійної діяльності, науки та/або інновацій, забезпечення запланованого рівня особистісного та професійного розвитку здобувачів вищої освіти;

- формування уміння творчо застосовувати в практичній діяльності прогресивні андрагогічні наукові ідеї, педагогічні інновації, практичний досвід навчання дорослих;

- формування власного стилю педагогічної діяльності, уміння визначати переваги та доцільність вибору тих чи тих наукових поглядів щодо теоретичних основ педагогіки дорослих у процесі професійної діяльності.

Зазначимо, що передумовами вивчення навчальної дисципліни є 
набуті раніше компетентності та результати навчання з освітніх компонент: Педагогіка вищої школи, Моделювання освітньої підготовки і професійної діяльності фахівця, Теорія і практика вищої професійної освіти в Україні, Основи андрагогіки, Основи медіаосвіти дорослих, Професійний імідж педагога-андрагога.

Виокремимо програмні компетентності, що будуть сформовані у здобувачів після успішного завершення вивчення курсу:

- загальні компетентності: здатність до самонавчання впродовж життя, самовдосконалення та саморозвитку; розуміння, що сучасні знання $€$ пріоритетними цінностями в житті людини в умовах інфрормаційного суспільства; здатність до постійного пошуку, аналізу, апробації раціональних шляхів, умов, методів, засобів, форм ефективного вирішення конкретних завдань виховання, освіти та навчання дорослих;

- фрахові компетентності: здатність до розуміння (теорія) і підтримки (практика) освіти дорослих упродовж усього життя, виявлення потенційних зв'язків у контексті освіти дорослих 3 андрагогікою, субдисципліною педагогіки, яка обґрунтовує напрями та організаційнометодичні засади андрагогічної моделі навчання дорослої людини; здатність розглядати історію розвитку теорії та практики освіти дорослих і андрагогіки в умовах неперервної професійної освіти та порушувати проблеми навчання та виховання дорослих у контексті життєвого шляху людини, іiї духовного розвитку та переживання вікових криз на різних етапах професіогенезу; розуміння цілей і особливостей освіти дорослих в історії педагогічної думки як складової системи неперервної освіти, ії̈ спрямованості на розвиток особистості, творчих здібностей, професійної кваліфікації.

Привернемо увагу до очікуваних результатів навчання. Так, здобувачі повинні: уміти здобувати інформацію з різних джерел у зрозумілому вигляді, демонструвати знання основних концепцій, розуміння теоретичних і практичних проблем, історії розвитку та сучасного стану наукових знань у зарубіжному й вітчизняному освітньому просторі щодо освіти дорослих, працювати з різними навчально-методичними матеріалами та критично оцінювати їх, використовуючи інформаційнокомунікаційні технології; уміти упевнено оперувати набутими знаннями у вирішенні завдань щодо освіти дорослих, робити аргументовані висновки, вільно висловлювати власні судження та публічно представляти результати досліджень та інновацій в галузі освіти дорослих, обговорювати та дискутувати з науково-професійною спільнотою, презентувати власне розуміння питань з історії розвитку теорії та практики освіти дорослих і андрагогіки; здійснювати аналіз, узагальнення наукової інформації, володіти термінологією з історії розвитку теорії та практики освіти дорослих і андрагогіки та оцінювати ії за критеріями ефективності застосування в навчанні дорослих.

Слід зазначити, що програма навчальної дисципліни містить такі теми:
1. Історико-педагогічний
та
прикладний
аспекти
розвитку 
андрагогіки.

2. Андрагогіка і вища педагогічна школа в умовах неперервної освіти: теоретичні й практичні аспекти.

3. Професійна діяльність викладача вищої школи: суспільні виклики та проблеми змісту підготовки.

4. Генезис пріоритетних тенденцій освіти дорослих в Україні (II пол. XIX - 20-ті рр. XX ст.).

5. Навчання впродовж життя як пріоритетний напрям освіти працюючої молоді та дорослих (друга пол. XX - початок XXI ст.).

6. Міжнародний досвід організації навчання людей третього віку.

Найбільш доцільними $€$ такі методи навчання: поєднання традиційних та інтерактивних методів навчання 3 використанням інноваційних технологій: словесні методи: лекція (проблемна, лекція 3 розгляду конкретних ситуацій, лекція-роздум, лекція-консультація, круглий стіл, мультимедійна тощо), пояснювально-ілюстративні, репродуктивні, бесіда, диспут, дискусія за матеріалами лекції та вивчених літературних джерел, семінар-дебати, семінар-діалог, вирішення проблемних ситуацій, семінар-вирішення ситуаційних задач, аналіз конкретних ситуацій (casestudy); наочні методи: спостереження, демонстрація; практичні методи: обробка довідкової інформації, тезування, рецензування, самостійна робота (робота із друкованими та електронними інформаційними ресурсами, виконання завдань: конспектування, анотування, написання есе); відеометод: дистанційні, мультимедійні.

На нашу думку, після успішного вивчення навчальної дисципліни здобувач вищої освіти зможе: критично осмислювати теорії, основні концепції педагогічних технологій навчання дорослих, особливості їх застосування під час організації конкретного освітнього процесу; обирати технології навчання залежно від стратегічних цілей і завдань, що вирішуються в педагогічному процесі, рівня навченості, вихованості дорослих, забезпечувати їх навчально-методичний супровід; розширювати фахові компетенції та особистісний потенціал педагога-андрагога.

Висновки і перспективи подальших досліджень. Вивчення навчальної дисципліни «Історія розвитку теорії та практики освіти дорослих і андрагогіки», мета якої - забезпечення загальної теоретичної і практичної підготовки здобувачів другого (магістерського) рівня вищої освіти з питань історії розвитку теорії та практики освіти дорослих у контексті безперервного становлення особистості, сприяє опануванню майбутніми викладачами закладів вищої освіти особливостями провадження практичної роботи педагога-андрагога, розв'язання комплексних проблем у галузі професійної діяльності, використання набутого досвіду в освітній, науковій та супровідній діяльності.

Перспективним напрямом вважаємо подальше дослідження проблеми історії розвитку теорії та практики освіти дорослих та андрагогіки в залежності від напрямів майбутньої професійної та наукової діяльності фахівців освітньої галузі. 


\section{Список використаних джерел}

Аніщенко, О.В., Лук'янова, Л.Б., Зінченко, С.В., Баніт, О.В. \& Дорошенко, Н.І. (2013). Сучасні технології освіти дорослих: посібник. Кіровоград : Імекс-ЛТД.

Беспарточна, О.І. (2014). Вивчення андрагогіки як навчальної дисципліни: теоретико-методологічний аспект. Педагогіка фрормування творчої особистості у вищій і загальноосвітній школах, 37 (90), 88-92.

Лук'янова, Л.Б. (2014). Андрагогіка: ретроспективний аналіз походження терміну та особливості сучасного змістового наповнення. Освіта дорослих: теорія, досвід, перспективи, 2, 107-116.

Мельниченко, О. (2020). Андрагогічні принципи освіти дорослих та забезпечення якості неперервної педагогічної освіти. Педагогічна освіта: Теорія і практика. Психологія. Педагогіка, (33), 24-30. URL: https://doi.org/10.28925/2311-2409.2020.33.3

Тимчук, Л.І. (2016). Становлення та розвиток андрагогіки як теорії $i$ практики освіти дорослих в Україні (кінець XIX-XX століття): авторефр. дис. ... д-ра пед. наук. Тернопіль. URL: http://dspace.tnpu.edu.ua/handle/123456789/6313

\section{References (translated and transliterated)}

Anishhenko, O.V., Luk'janova, L.B., Zinchenko, S.V., Banit, O.V. \& Doroshenko, N.I. (2013). Suchasni tekhnologhiji osvity doroslykh [Modern technologies of adult education]: posibnyk. Kirovoghrad: Imeks-LTD [in Ukrainian].

Bespartochna, O.I. (2014). Vyvchennja andraghoghiky jak navchaljnoji dyscypliny: teoretyko-metodologhichnyj aspekt [The study of andragogy as a discipline: theoretical and methodological aspect]. Pedaghoghika formuvannja tvorchoji osobystosti u vyshhij i zaghaljnoosvitnij shkolakh Pedagogy of formation of creative personality in higher and general education schools, 37 (90), 88-92 [in Ukrainian].

Luk'janova, L.B. (2014). Andraghoghika: retrospektyvnyj analiz pokhodzhennja terminu ta osoblyvosti suchasnogho zmistovogho napovnennja [Andragogy: a retrospective analysis of the origin of the term and features of modern content]. Osvita doroslykh: teorija, dosvid, perspektyvy - Adult education: theory, experience, prospects, 2, 107-116 [in Ukrainian].

Meljnychenko, O. (2020). Andraghoghichni pryncypy osvity doroslykh ta zabezpechennja jakosti neperervnoji pedaghoghichnoji osvity [Andragogical principles of adult education and quality assurance of continuing pedagogical education]. Pedaghoghichna osvita: Teorija $i$ praktyka. Psykhologhija. Pedaghoghika - Pedagogical education: Theory and practice. Psychology. Pedagogy, (33), 24-30 [in Ukrainian].

Tymchuk, L.I. (2016). Stanovlennja ta rozvytok andraghoghiky jak teoriji i praktyky osvity doroslykh $v$ Ukrajini (kinecj XIX - XX stolittja) [Formation and development of andragogy as a theory and practice of adult education in Ukraine (late XIX-XX centuries)]. Extended abstract of Doctor's theses. Ternopilj [in Ukrainian]. 